Muh. As'ad

\title{
KEHIDUPAN KEAGAMAAN DAN BUDAYA MAS YARAKAT DIKOTA JAYAPURA PROVINSI PAPUA
}

\author{
$01 \mathrm{eh}:$ Muh.As'ad
}

\begin{abstract}
This research was conducted in Jayapura, Papua. This research aims to describe the role of traditional government in maintaining social harmony in Jayapura society. This used qualitative method, where data was collected by interview. Than, data was analyzed by descriptivequalitative.

This research indicates that the traditional government has a good role andfunction in maintaining social harmony in Papua society. The charisma of traditional leader (tribal leader) is most important factor. His words will be listened and his order will be obey. The social conflict among the people or between two tribal could be healed by this tribal leader intervention.
\end{abstract}

Key words: traditional government, social harmony.

\section{PENDAHULUAN.}

$\mathrm{M}$

eski banyak asumsi yang menolak keterkaitan identitas agama dan etnisitas sebagai latar belakang munculnya konflik di Indonesia (seperti Ambon, Poso, Aceh, Papua dan sebagainya yang dianggap muncul dari ranah politik), namun kenyataannya semangat beragama dan semangat etnisisme menjadi konteks pendukung (facilitating context) yang memengaruhi konflik tersebut menjadi panjang, lebar dan (mungkin) laten. Ini berarti relasi antar agama dan etnik di Indonesia memiliki potensi konflik yang luar biasa besarnya. Tentu saja hal ini seharusnya menjadi perhatian utama dari pemerintah baik pusat maupun lokal. 
Muh. As'ad

Pendekatan keamanan yang selama ini menjadi instrumen utama dalam pencegahan konflik dan pemeliharaan kerukunan mungkin efektif pada situasi tertentu atau dalam situasi yang bersifat aksidental. Tetapi pendekatan keamanan tidak mampu secara permanen "menjaga" dan memelihara kerukunan'antar umat. Ini karena pendekatan keamanan lebih mengedepankan aspek stabilitas ketimbang aspek harmoni. Pendekatan keamanan sangat tidak respek terhadap dinamisasi masyarakat yang kadang-kadang saling berbenturan.

Oleh karena itu, pemanfaatan institusi lokal yang tumbuh dan berkembang seiring dengan pertumbuhan masyarakat perlu untuk dilakukan. Institusi lokal seperti pemerintahan adat merupakan lembaga sosial yang memiliki pengaruh yang kuat bagi warganya. Biasanya daerah yang memiliki pemerintahan adat yang kuat, situasi sosialnya relatif aman. Kalaupun ada konflik yang terjadi, secara cepat dapat teratasi. Ini karena pemerintahan adat biasanya memiliki mekanisme penyelesaian konflik yang telah menjadi konsensus sosial antar suku.

Penelitian ini merupakan bagian dari upaya untuk mengidentifikasi potensi lembaga pemerintahan adat sebagai instrumen pengelolaan konflik sosial. Berdasarkan itu, penelitian ini mengangkat permasalahan yaitu: bagaimana peran lembaga adat sebagai instrumen pemeliharaan kerukunan antar masyarakat?

\section{METODE PENELITIAN}

Lokasi Penelitian adalah Kota Jayapura. Pemilihan lokasi ini secara teknis karena Kota Jayapura sebagai salah satu wilayah kerja Balai Litbang Agama Makassar, selain itu penetapan lokasi dipermantap dengan adanya penciuman lapangan yang dilakukan oleh Tim Balai Litbang dengan maksud mengidentifikasi kemungkinan diadakannya penelitian tentang pemerintahan adat dan potensinya dalam menjaga dan memelihara kerukunan.

Informan dalam penelitian ini terdiri dari tokoh adat, tokoh masyarakat, pemerintah dan masyarakat umum. Penetapan informan dengan cara purposive sampling atau dengan kata lain penetapan informan didasarkan pada kriteria-kriteria tertentu yang oleh peneliti dianggap mampu untuk memberikan informasi mengenai obyek kajian penelitian. Data yang ingin digali dari para informan adalah pandangan dan pengalaman mereka terhadap peran lembaga

pemerintahan adat dalam melakukan pemeliharaan kerukunan masyarakat di Papua yang sangat multikultural. 
Pengolahan dan analisis data dilakukan dengan menelaah seluruh data yang tersedia dari berbagai sumber, yaitu hasil wawancara, catatan lapangan, dokumen-dokumen, gambar, foto dan lain-lain. Kemudian mereduksi data, selanjutnya menyusun ke dalam satuan-satuan, lalu dikategorisasi, kemudian disusun dalam bentuk tulisan deskriptif.

\section{TEMUAN DAN PEMBAHASAN}

\section{A. Kehidupan Beragama Masyarakat}

Penduduk Kota Jayapura yang beragama Kristen jumlahnya paling besar di banding agama-agama lainnya. Dari penduduk yang berjumlah 211.852jiwa, sebanyak 90.325 orang $(42.64 \%)$ yang beragama Kristen. Penduduk yang bergama Islam jumlahnya cukup besar, yaitu 86.378 orang (38.5\%). Namun demikian, terdapat distrik yang penduduknya beragama Islam jumlahnya paling besar, yaitu Distrik Abepura. Dari penduduknya yang berjumlah 77.310 jiwa, yang beragama Islam sebanyak 33.825 jiwa $(43,75 \%)$; sedang yang beragama Kristen berjumlah 30.431 jiwa $(39,36 \%)$. Komposisi penduduk Kota Jayapura berdasarkan pemelukan agama terlihat pada tabel 1 .

Pada umumnya penduduk Kota Jayapura yang beragama Kristen (penduduk asli). Sedang yang beragama Islam kebanyakan para pendatang dari provinsi-provinsi di Indonesia seperti Sulawesi Selatan (Bugis-Makassar). Orang Papua yang beragama Islam di Kota Jayapura kebanyakan berasal dari Fak-Fak, yang terkenal sebagai wilayah Papua yang bersentuhan dengan Islam sejak abad ke-16.

Perkembangan agama Kristen di Papua dimulai pada pertengahan abad ke-19 dengan datangnya dua orang misionaris Kristen dari Jerman, Ottow dan Guissler pada tanggal 5 Pebruari 1855. Keberhasilan para misionaris dalam mengembangkan agama Kristen di Papua antara lain karena didukung oleh pemerintah penjajah Belanda. Sehubungan dengan keberhasilan itu, tanggal 5 Pebruari setiap tahun, selalu diperingati masuknya Injil di Papua dan dijadikan sebagai hari libur dalam Provinsi Papua oleh pemerintah. 
Tabel.1

Komposisi Penduduk Kota Jayapura Berdasarkan Pemelukan Agama

Tahun 2005

\begin{tabular}{|l|l|l|}
\hline Agama & Jumlah Pemeluk & Pro sent as e \\
\hline Kristen & 90.325 & 42,64 \\
Islam & 86.378 & 40,77 \\
Katholik & 32.211 & 15.20 \\
Hindu & 1.878 & 0,89 \\
Budha & 1.060 & 0,50 \\
Penduduk & 211.852 & 100.0 \\
\hline
\end{tabular}

Sumber : Kota Jayapura dalam Angka 2005 (diolah)

Para pemeluk agama tersebut berusaha mendirikan rumah-rumah ibadah sebagai pusat kegiatan keagamaan mereka. Rumah ibadah penganut agama Kristen paling besar jumlahnya, mencapai 140 buah dan tersebar pada keempat distrik yang ada. Sedang rumah ibadah bagi umat Islam jumlahnya juga cukup besar, yaitu 129 buah berupa masjid 99 buah dan mushallah 30 buah. Jumlah rumah ibadah di Kota Jayapura terlihat pada tabel 2.

Besarnya jumlah rumah ibadah bagi penganut Kristen dikarenakan banyaknya sekte atau aliran dalam lingkungan mereka. Penganut agama Kristen di Kota Jayapura terdiri atas 24 sekte (induk organisasi gereja). Sekte yang besar pengaruhnya dilihat dari banyaknya gereja yang dibina adalah Gereja Kristen Injili (GKI) dan Gereja Pantekosta di Indonesia GPDI). Di samping kedua sekte tersebut terdapat sekte-sekte lainnya, yaitu Gereja Bethel Indonesia (GBI), Gereja Bethel/Gereja Pantekosta (GB/GP), Gereja Injil di Indonesia (GIDI), Persekutuan Gereja-Gereja Baptis Indonesia Irian Jaya (GBIJ), dan Gereja Masehi Adven Hari Ketujuh (GMAHK).

Tabel 2

Banaknya Rumah Ibadah Masing-Masing Agama pada Tiap-Tiap Distrik di Kota Jayapura, Tahun 2005.

\begin{tabular}{|l|c|c|c|c|c|c|}
\hline Kecamatan & Islam & Kristen & Katholik & Hindu & Budha & Jumlah \\
\hline Abe pur a & 38 & 36 & 5 & - & - & 79 \\
Jayapura Selataii & 35 & 52 & 5 & 1 & 2 & 95 \\
Jayapura Utara & 47 & 36 & 16 & - & - & 99 \\
Muara Tami & 9 & 16 & 4 & - & - & 29 \\
\hline Kota jayapura & 129 & 140 & 30 & 1 & 2 & 302 \\
\hline
\end{tabular}

Sumber : Kota Jayapura dalam Angka, Tahun 2005 (diolah). 
Upaya penyebarluasan ajaran agama serta intensifikasi bimbingan dan penyuluhan agama di kalangan umat beragama dilakukan oleh pemuka, tokoh, ataupun pemimpin masing-masing lembaga keagamaan bersangkutan, baik melalui rumah-rumah ibadah secara rutin dan berkala maupun melalui kegiatan sosial keagamaan seperti kegiatan peringatan hari bersejarah yang bersifat keagamaan, kegiatan sosial tradisi keagamaan, kegiatan perkumpulan kaum ibu dan remaja.

Kerukunan hidup beragama, baik intern maupun antar umat beragama, cukup baik, sebagaimana pengakuan tokoh-tokoh dari masing-masing agama serta dari kalangan pemerintah dan pejabat terkait. Bimbingan dan pembinaan yang intensif mengenai kesadaran berbangsa dan bermasyarakat serta kesadaran menjaga dan memperta-hankan citra kemuliaan agama yang diberikan oleh pemerintah selama ini melalui berbagai kegiatan penataran P4 (lintas sektoral) serta kegiatan pembi-naan khusus dari instansi terkait, rupanya memberikan motivasi yang cukup berarti bagi masyarakat yang sekalian juga adalah umat beragama untuk herupaya terus menjalin hubungan baik antara berbagai kelompok agama yang berbeda faham keagamaan serta antara umat beragama yang berbeda agama.

Dalam upaya mengatasi masalah-masalah sosial yang terkadang diisukan sebagai masalah perbedaan agama, wadah "tiga tungku" memiliki fungsi dan peranan yang cukup efektif. Dimaksudkan dengan wadah "tiga tungku" di sini ialah suatu badan musyawarah di tingkat desa atau kelurahan yang anggotaanggotanya terdiri dari tiga unsur yakni (I) pemerintah, dalam hal ini pejabat desa atau kelurahan, (2) tokoh adat, dan (3) tokoh atau pemuka agama.

Kehidupan beragama di Kota Jayapura berjalan dengan baik, rukun, harmonis dan cukup toleran. Sampai penelitian ini dilakukan, tidak ditemukan informasi adanya konflik yang melibatkan antar umat beragama. Konflik yang sering terjadi di Papua adalah konflik antar suku dan konflik antara masyarakat atau suku dengan perusahaan atau pemerintah dengan isu monopoli kekuasaan, jabatan, dan kekayaan yang dianggap memarginalkan orang Papua dan menghilangkan hak-hak adat orang Papua. Tidak terjadinya konflik yang melibatkan umat beragama disebabkan oleh beberapa faktor pertama sikap pemerintah yang selalu berusaha mengembangkan kerukunan hidup beragama, kedua meningkatnya kesadaran warga kota untuk melaksanakan ajaran agama dan keyakinan masing-masing dengan lebih berkualitas, dan ketiga peran yang dilakukan oleh tokoh-tokoh agama dan rohaniawan yang ada di kota ini. 
Wadah kerukunan antar umat beragama telah terbentuk di Kota Jayapura pada tahun 2004 dengan nama Badan Koordinasi Kerukunan Hidup Antar Umat Beragama (BKKHAUA). Badan ini terbentuk atas kesepekatan para tokoh agama dalam satu pertemuan yang mewakili lima lembaga agama yaitu Majelis Ulama Indonesia (MUI), Persekutuan Gereja-Gereja Indonesia (PGI), Majelis Agung Wali Gereja, Parisada Hindu Dharma, dan Lembaga Umat Budha.

Aktivitas Badan Koordinasi Kerukunan Hidup Antar Umat Beragama masih terbatas pada pertemuan rutin pengurus dan pertemuan dengan pemerintah, dan program kerja yang telah disusun belum berjalan sebagaimana yang diharapkan karena tidak mendapat dukungan dana dari pemerintah.

Sebelum berdiri Badan Koordinasi Kerukunan Hidup Antar Umat Beragama (BKKHAUA) di Kota Jayapura, telah terbentuk wadah seperti itu di tingkat provinsi, yaitu pada tahun 1998. Pembentukan wadah ini dilakukan untuk mengantisipasi adanya pengaruh kerusuhan yang terjadi di Situbondo, yang dapat menggoncangkan kehidupan antar umat beragama. Setelah terbentuk, wadah ini tidak melakukan aktivitas dan kegiatan sebagaimana yang diprogramkan. Lembaga ini tidak berjalan sebagaimana yang diharapkan karena ide pembentukannya hanya berasal dari pemerintah, dengan tujuan agar kehidupan masyarakat tidak mengalami kegoncangan. Selain itu, lembaga ini tidak ditunjang oleh dana yang memadai dari pemerintah.

Pertemuan tokoh-tokoh agama sering dilakukan oleh pemerintah, baik pemerintah daerah maupun Departemen Agama. Pertemuan itu merupakan kegiatan pemerintah dalam rangka pembinaan kerukunan hidup antar umat beragama. Selain itu, pertemuan tokoh-tokoh agama dilakukan oleh pemerintah. jika muncul hal-hal yang dapat mengganggu kehidupan beragama masyarakat, misalnya munculnya kelompok lasykar jihad, dan adanya pengungsi kerusuhan yang masuk di Papua, ketika terjadinya konflik yang bernuansa agama di Ambon.

Pengurus BKKHUA Kota Jayapura diangkat oleh Walikota Jayapura dengan Surat Keputusan No. 41 Tahun 2004. Menurut SK Walikota, tugas badan ini adalah pertama membina kerukunan umat beragama, kedua membangun kerjasama Lembaga keagamaan dengan pemerintah, ketiga membina pengamalan ajaran agama, keempat membina dan memberdayakan pemuda dan perempuan di lingkungan tempat ibadah, dan kelima memberikan informasi dan mempublikasikan kegiatan yang berhubungan pembinaan kerukunan umat beragama. 


\section{B. Kehidupan Sosial Budaya Masyarakat.}

\section{Suku Papua}

Papua (Provinsi Papua dan Provinsi Irian Jaya Barat) mempunyai 57 kelompok etnis dan 252 macam bahasa, dengan adat istiadat, seni karya, seni budaya yang unik dan beraneka ragam (Kapitalisasi: 173). Berkaitan dengan keaneka ragaman bahasa suku Papua, timbul pandangan bahwa suku asli yang tinggal di Papua mencapai sekitar 250. Masing-masing suku memiliki bahasa serta karakteristik tertentu. Mereka yang tinggal di dataran tinggi berbeda dalam banyak hal dari mereka yang tinggal di dataran rendah, daerah pesisir dan pulaupulau kecil (Membangun Budaya Damai: 106).

Walaupun bangsa Papua sangat berbeda-beda suku dan bahasanya, namun terdapat suatu kesamaan yang sangat kuat dalam asal usul, dan latar belakang budayanya (rumpun Melanesia/Austronesia). Tidak sulit untuk saling mengakui kesamaannya, sambil menerima bahwa seorang Papua dari wilayah Mimi Ka atau Biak memang sangat berbeda dengan seorang Papua yang berasal dari Puncak Jaya atau Lembah Balim. Terdapat suatu kekayaan dalam keaneka ragaman itu, seperti unsur kesamaan hayati lebih kuat dari pada unsur perbedaan (Membangun Budaya Damai: 9).

Keragaman penduduk Papuajuga diperkaya berbagai etnis non-Melanesia yang telah lama menjadi penduduk tanah ini, bahkan ada yang sudah di Papua hingga lebih dari tiga generasi (Profil Otonomi: 15-16).

\section{Sistem Kekerabatan}

Orang-orang Papua menghitung keturunan melalui garis keturunan lakilaki (patriliea), setiap individu menggunakan nama keturunan berdasarkan klan ayah sebagai identitas dalam masyarakat (Suatu Deskrepsi:40). Sistem patrilinea ini menempatkan wanita sebagai masyarakat kelas dua dilihat dari segi keturunan, artinya pihak wanita tidak berhak menganulir keturunan anaknya. Anak-anak merupakan anggota klan ayahnya

Klan merupakan sekat-sekat masyarakat yang membedakan masyarakat satu dengan masyarakat lainnya, terutama dalam memelihara keturunan. Anggota masyarakat suatu klan mempunyai keterikatan kekeluargaan yang sangat akrab, bagaikan suatu saudara. Perwujudan kekerabatan demikian ini tampak pada berbagai hal. Larangan kawin sesama klan berlaku pada berbagai masyarakat Papua, seperti di Kampung Nafri. Martabat dan prestise klan merupakan tanggung jawab bersama dalam klan itu. 
Muh. As'ad

Pada masyarakat Nafri kekuasaanlah yang menjadi perbedaan kedudukan setiap anggota masyarakat yang tinggi, yang menengah, maupun anggota masyarakat yang rendah. Secara histories klan Awi berhak sebagai penguasaan orang-orangnya berada pada struktur sosial teratas. Kepala-kepala klan sebagai bawahan ontofro yang berkuasa atas klan-klannya dan bertugas menyampaikan perintah dari ontofro kepada rakyatnya tergolong dalam lapisan sosial yang kedua atau menengah setelah orang-orang dari klan Awi. Sedangkan lapisan sosial atau struktur sosial terrendah adalah rakyat biasa yang tidak mempunyai jabatan dalam pemerintahan adat masyarakat Nafri (Suatu Deskrepsi:39).

Pelapisan sosial pada saat ini tidak begitu diperhatikan, namun kelompok yang berkuasa seperti ontofro, pembantu, pesuruh, dan kepala-kepala klan masih dipandang sebagai kelompok sosial teratas.

\section{PEMERINTAHAN ADAT SEBAGAI BASIS KERUKUNAN DI KOTA JAYAPURA}

\section{A. Deskrepsi Pemerintahan Adat di Kota Jayapura}

Seperti telah dikemukakan, di Kota Jayapura khususnya dan di Provinsi Papua umumnya, diberlakukan otonomi khusus. Salah satu kekhususan adalah pengakuan atas lembaga masyarakat adat atau pemerintahan adat yang telah diwarisi secara turun temurun. Struktur pemerintahan adat ini merupakan nilai lokal yang memegang peranan penting dalam kehidupan masyarakat Papua.

Lembaga masyarakat adat di Papua pada masa pemerintahan Belanda diakui dan dibentuk, sehingga pada saat itu urusan pemerintahan mulai dari Bestuur setingkat distrik langsung membawahi beberapa kampung. Kepala kampung inilah membawahi setiap keret yang merupakan satu persekutuan. Pada masa Pemerintahan Indonesia, jabatan kepala kampung itu hilang diganti dengan kepala desa atau lurah (Kapitalisasi: 1960).

Koentjaraningrat menggambarkan pemerintahan kampung atau desa pada masa pemerintahan Belanda dengan mengatakan, desa-desa baru itu oleh Pemerintah Belanda diberikan suatu sistem pimpinan baru yang demi keseragaman, modelnya diambil dari masyarakat-masyarakat desa penduduk Teluk Jayapura dan Danau Sentani. Di daerah-daerah tersebut masyarakat desa mengenal tokoh yang ahli mengenai persoalan tanah, yaitu ondowafi. yang tugasnya mengawasi pembukaan tanah ulayat oleh para penggarap, menyaksikan transaksi tanah atau hutan-hutan sagu, dan sebagainya. Para ondowafi itu dianggap ahli adat dalam desa, yang terutama mengetahui riwayat tanah-tanah yang ada di wilayah desanya. Pemerintah Belanda kemudian 
mengangkat para ondowafi sebagai pejabat desa resmi, di samping seorang pejabat lain yaitu seorang korano (Masyarakat: 66).

Tipe kepemimpinan adat yang terdapat pada masyarakat Papua di Kota Jayapura dikelompokkan ke dalam tipe kepemimpinan kepala siiku. Ciri kepemimpinan ini adalah terikat pada sistem keturunan bilogis. Sistem pewarisan kedudukan pada dasarnya dari ayah kepada anak laki-laki sulungnya. Namun bila pemimpin adat yang diganti tidak memiliki anak laki-laki, maka kedudukan itu berpindah kepada saudara laki-lakinya.

Istilah yang dipergunakan untuk kepala suku dalam masyarakat Papua bermacam-macam, seperti: ondoafi, ondofolo, dan ontofro. Di kalangan masyarakat Sentani dipergunakan istilah ondoafi atau ondofolo, dan dikalangan masyarakat Nafri dipakai istilah ondoafi atau ontofro.

Dalam struktur pemerintahan adat, pucuk pimpinan tertinggi terletak di tangan kepala persekutuan masyarakat adat (ondoafi, ondofolo, dan ontofro). Kepala suku sebagai pemegang kekuasaan tertinggi dalam masyarakat mempunyai pengaruh besar sekali terhadap segala-galanya yang berhubungan dengan kebutuhan hidup anggota kelompoknya, termasuk tanah, air, dan segala tumbuhan serta hewan yan hidup di atas atau di dalamnya. Segala peraturan yang mengatur penguasaan, pemilikan, dan penggunaan tanah tersebut ditentukan olehnya.

Di dalam menjalankan kepemimpinan adat, kepala suku tidak bekerja sendiri, tetapi mempunyai semacam perangkat birokrasi. Kepala suku mempunyai sejumlah pembantu dengan tugas dan wewenang tertentu. Jabatan-jabatan dalam kepemimpinan antara lain pesuruh dan penghubung. Kepala suku mempunyai dan membawahi sejumlah kepala klan atau kepala kerek yang membantunya melaksanakan tugas dan tanggung jawabnya.

Dalam hal pengambilan keputusan, kepala suku tidak bersifat otoriter, ia memperhatikan aspirasi dari bawah. Keputusan yang diambil merupakan konsensus seluruh perangkat yang tergabung dalam lembaga adat sebagai wadah penentu pengambilan keputusan.

Pada masyarakat Nafri, ontofro sebagai pemimpin informal yang tertinggi pada masyarakat dapat menjalankan tatanan pemerintahan tradisional sebagi salah satu wujud dari pewarisan nilai-nili adat. Segala aktivitas yang dilakukan oleh ontofro baik internal maupun eksternal selalu hams bersumber pada normanorma yang mengatur akan tugasnya yang diwariskan oleh pemimpin adat terdahulu secara turun temurun (69-70).

Pada dasarnya struktur pemerintahan adat pada setiap kampung memiliki persamaan. Perbedaannya terkait dengan kondisi setiap suku dari segi luas 
kekerabatannya. Ada kampung yang berstruktur "tungal" artinya seorang ondoafi membawahi beberapa klan; ada juga berstruktur "ganda", yaitu dua ondoafi masing-masing dengan strukturnya mengatur suatu kampung; dan berstruktur "bertingkat", yaitu seorang ondoafi membawahi ondoafi-ondoafi lain bersama strukturnya.

Golongan berstruktur "ganda" yaitu di Kampung Nafri Kota Jayapura. Struktur pemerintahan adat pada masyarakat Nafri merupakan gabungan atau kerjasama dua struktur yang berdiri sejajar. Terdapat dua ondofolo yang masing-masing dengan struktur dan wilayahnya. Nafri Barat disebut Warke dan Nafri Timur disebut Sembekra. Nafri Barat dan Nafri timur masing-masing dikepalai oleh seorang Ondoafi. Ondoafi Warke sekarang bernama Drs.George Arnol Awi dan Ondoafi Sembekra bernama Gerson Soni Awi, SH. Masing ondoafi mempunyai mag (pesuruh). Ondoafi Warke magnya. dari suku Wamoar dan membawahi 4 (empat) kepala suku pertama nero, kedua fingkreuw. ketiga uyo, dan keempat tjoe. Sedang mag dari ondoafi Senberkra Suku Marhabia. Juga membawahi 4 (empat) kepala suku yang membantunya pertama marhabia, kedua taniau, ketiga hanuebi, dan keempat wamiau. Masing-masing ondoafi memiliki masyarakat dan keduanya bekerja sama korelasi satu sama lain untuk membantu mengembangkan tugasnya membina masyarakat yang baik adil dan makmur sesuai kehendak dan cita-cita ondoafi yang ada. Dalam suku Marhabia bergabung suku Mra-Mra dan suku Kay (wawacara).

Di Kota Jayapura, persekutuan-persekutuan adat yang berjumlah 14 kampung membentuk suatu persekutuan informal dengan nama Lembaga Masyarakat Adat. Lembaga ini, meskipun semacam forum komunikasi tetapi mempunyai struktur organisasi tersendiri.

\section{B. Fungsi dan Peran Pemerintahan Adat}

Sebagai penguasa adat, kepala suku (ondoafi, ondofolo, dan ontofro) dan kepala klan berlanggung jawab untuk melindungi seluruh potensi alam masyarakat. seperti tanah, hutan, lahan sagu, potensi laut, dan lainnya agar dapat dikelola dan dimanfaatkan secara baik dan bertanggung jawab. Oleh sebab itu setiap aktivitas yang dilakukan terhadap potensi alam ini, baik oleh penduduk asli mapun penduduk pendatang, harus mendapat izin atau persetujuan dari niL'ieka.

Meskipun kepala suku memiliki peranan sebagai pelindung kekayaan yang terdapat di atas tanah adat bagi kehidupan masyarakat; menguasai tanah untuk dipergunakan bagi kepentingan seluruh anggota masyarakatnya; namun kekuasan ini hanya terbatas pada kapasitasnya sebagai pemimpin adat. Kepala- 
kepala klan yang berhak untuk mengatur tanah-tanah adat yang menjadi milik klannya.

Pada masyarakat Nafri, misalnya, tugas dan wewenang ontofro (kepala suku), antara lain:

1. Ontofro merupakan pelindung bagi masyarakat adatnya dan sekaligus pelindung terhadap sumber-sumber alam bagi kehidupan ekonomi warganya;

2. ontfro sebagai pengawas yang mengawasi pelaksanaan adat istiadat, menjaga ketertiban dan keamanan penduduk serta mengatur dan mengawasi masalah-masalah berkaitan dengan perkawinan dan sistem pewarisan;

3. ontofro juga berkewajiban untuk menanggulangi dan menyelesaikan masalah-masalah dalam masyarakat agar tidak terjadi perpecahan sehingga hubungan kekerabatan mereaka tetap terjalin secara akrab sebagai suatu masyaakat yang memiliki kesamaan keturunan; dan

4. ontofro merupakan pengambil keputusan dan selaku penanggung jawab atas wilayah kekuasaannya (Deskrepsi:72).

\section{Manfaat Pemerintahan Adat terhadap Kerukunan}

Keberadaan pemerintahan adat sebagai pranata sosial sangat mendukung terpeliharanya kerukunan dan keharmonisan dalam masyarakat. Secara internal kepala suku sebagai pimpinan tertinggi dalam masyarakatnya mempunyai kharsima dan kewibawaan yang sangat berpengaruh. Katakatanya didengar dan perintahnya ditaati. Setiap permasalahan antara anggota masyarakat dalam sukunya dapat terselesaikan dengan cepat berkat kharisma dan kewibawaan itu.

Secara eksternal, bila terjadi permasalahan dengan masyarakat di luarnya penyelesaiaannya dapat juga terselesaikan dengan cepat lewat lembaga adat itu. Pertemuan-pertemuan antara tokoh masyarakat tentunya selalu mengacu pada rasionalitas yang bijak. Pertimbangan akal akan didahulukan dari pada dorongan emosi. Hal ini memudahkan munculnya kesepahaman dan kesepakatan yang menjamin rasa adil, dalam arti tidak ada pihak yang diuntungkan sementara pihak lain dirugikan. Pihak yang bersalah secara sadar akan menanggung resiko kesalahannya. Keputusan atau kesepakan dari tokoh-tokoh masyarakat masingmasing pihak akan diterima dengan baik oleh masing-masing masayarakatnya. 


\section{Sistem Pelestarian Pemerintahan Adat di Kota Jayapura}

Seperti telah dikemukakan, pemberlakuan otonomi khusus di Papua mengakui keberadaan pemerintahan adat. Dengan demikian pelestarian lembaga adat ini melalui sistem politik yang berlaku khusus di Papua. Legalitas formal ini merupakan jaminan terhadap pemeliharaan dan pembinaan lembaga adat ini.

Jaminan secara politik ini tidak banyak berarti bila tidak ditunjang oleh komitmen kultural dari masyarakat pendukungnya. Pengakuan masyarat atas eksistensi lembaga pemerintahan adat ini tampak dengan jelas pada ketaatan anggota masyarakat terhadap nilai dan norma yang mendukung keberadaan lembaga adat itu.

Sebagai bagian dari pelestarian pemerintahan adat ini terdapat norma yang membentenginya, yaitu sangsi pelanggaran. Setiap prilaku anggota masyarakat adat harus selalu mengacu pada nilai dan norma yang berlaku dalam masyarakat adat itu. Di antara nilai dan norma itu adalah ketaatan kepada kepala suku sebagai figur sentral yang diyakini selalu berpikir untuk kepentingan seluruh masyarakatnya. Setiap masyarakat memiliki hukum adat sebagai hukum tidak tertulis yang berlaku dikalangan masyarakat itu.

Menyadari adanya hukum formal, pelanggaran-pelanggaran yang bersifat pidana akan diselesaikan lewat jalur hukum (pengadilan). Namun demikian, permasalah yang dapat diselesaikan secara damai atau kekeluargaan dapat diusahakan melalui lembaga adat.

Lembaga adat sebagai suatu nilai budaya lokal menuntut agar segenap warganya mengikuti norma-norma yang terbangun di atas nilai itu. Ketaatan kepada norma-norma itu merupakan suatu konsensus dalam masyarakat. Pelanggaran atas norma-norma itu akan mendapatkan sangsi sosial berupa pengucilan dari masyarakat.

\section{KESIMPULAN DAN SARAN}

\section{A. Kesimpulan}

1. Revitalisasi pemerintahan adat sebagai warisan budaya masyarakat Papua mendapatkan peluang besar dengan diberlakukannya otonomi khusus di Papua. 
2. Pemeliharaan dan pelestarian pemerintahan adat ini melalui sistem politik dengan legalitas formal yang ditetapkan melalui undang-undang otonomi khusus itu. Legalitas formal itu didukung oleh sistem budaya berupa ketaatan terhadap nilai dan norma adat. Sosialisdasi nilai dan norma ini melalui pendidikan dalam masyarakat.

3. Pemerintahan lokal di Kota Jayapura berfungsi menjaga kerukunan dan keharmonisan hidup, baik secara internal maupun eksternal dengan adanya kharisma dan kewibaan para tokoh adat terutama kepala suku.

\section{B. Saran-Saran}

Menyadari fungsi dan peran yang sangat vital lembaga pemerintahan adat di Kota Jayapura khususnya dan di Papua umumnya, maka pemanfaatan lembaga adat ini adalah kebijakan yang tepat. Pembinaan kerukunan hidup antar umat beragama khususnya dan kehidupan beragama umumnya melalui lembaga ini. Hal ini dapat dilakukan dengan melakukan pembinaan terhadap lembaga ini dan dengan bermitra dengannya.

\section{DAFTAR PUSTAKA}

Athwa, Ali. 2004. Islam atau Kristenkah Agama Orang Irian. Jakarta: Pustaka Dai.

Badan Pusat Statistik. 2006. Kota Jayapura dalam Angka 2005. Jayapura: BPS Kota Jayapura.

Broek, Theo van den dan Rudolf Kambayong OFM. 2006. Membangun Budaya Damai dan Rekonsiliasi DasarMmenangani Konflik di Papua. Jayapura: Sekretariat Keadilan dan Perdamaian Keuskupan Jayapura.

Bungin, Burhan. 2006. Analisis Data Penelitian Kualitatif. Jakarta: FT. Raja Grafindo Persada.

Hamid, Abu. tt. Nilai-Nilai dalam Adat Istiadat Orang Bugis/Makassar di Sulawesi Selatan. Makalah ketikan.

Isre, Moh.Soleh (ed). 2003. Konflik Etno Religius Indonesia Kontemporer. Jakarta: Puslitbang Kehidupan Beragama Badan Litbang Agama dan Diklat Keagamaan Departemen Agama RI.

Koentjaraningrat. 1980. Penagantar Ilmu Antropologi. Jakarta: Aksara Baru.

Koentjaraningrat dkk. 1994. Irian Jaya, Membangun Masyarakat Majemuk. Jakarta: Djambatan. 
Muh. As'ad

Koentjaraningrat (ed.). 1984. MasyarakatDesadiIndonesia. Jakarta: LembagaPenerbit Fakultas Ekonomi Universitas Indonesia. ]

Malak, Stepanus. 2006. Kapitalisaasi TanahAdat. Cetakan II. Bandung: Yayasan Bina Profesi Mandiri.

Muhadjir, H.Noeng. 2002. Metodologi Penelitian Kualitatif. Edisi IV Cetakan II. Yogyakarta: Rake Sarasin.

Muhaimin AG 2004. Damai di Dunia Damai untuk Semua Perspektif Berbagai Agama. Jakarta: Puslitbang Kehidupan Beragama Badan Litbang dan Diklat Keagamaan Departemen Agama RI.

Musa'ad, Muhammad Abud. 2004. Menguak Tabir Otsus Papua. Bandung: ITB.

Onim, J.F. 2006. Islam dan Kristen di Tanah Papua. Meniti jalan bersama Hubungan Islam-Kristen dalam Sejarah Penyebaran dan Perjumpaannya di Wilayah Semenanjung Onim Fakfak. Bandung: Jurnal Info Media.

Pemda Tingkat I Irian Jaya. 1998. Sejarah Kembalinya Irian Jaya ke Pangkuan Republik Indonesia. Jayapura: Pemda Irian Jaya.

Ramandey, Frist Bernard dkk. 2005. Profit Otonomi Khusus Papua. Jayapura: Aliansi Jurnalis Independen (AJI) Papua.

Rumaseb, Alex. 1997. Sejarah Masuk dan Berkembangnya Gereja Kemah Injil Indonesia di Irian Jaya 1938-1994. Bandung: Yayasan Kalam Hidup.

Rumainum, F.J.S. 1966. Sepuluh Tahun GK1 Sesudah Seratus Satu Tahun Zending di Irian Barat. Sukarnapura Irian Barat: Kantor Pusat GKI.

Rumbiak, yan Piter. 2005. Ptonomi Khusus bagi Provinsi papua. Menyelesaikan Pelanggaran Hak Asasi Manusia dan Membangun Nasionalisme di Daerah Krisis Integrasi. Jakarta: Papua International Educaton.

Salam, Ummi. 2003. Murtad Sebagai Alasan Perceraian di Pengadilan Agama Jayapura. Tesis. Makassar: Program Pascasarjana Universitas Muslim Indonesia.

Scheunemann, Rainer. 2004. Fajar Merekah di Tanah Papua, Hidup dan Karya Rasul Papua Johann Gottlob Geissler (1830-1870) dan Warisannya untuk Masa Kini. Jayapura: Panitia Junelium Emas 150 Tahun Hari Pekabaran lnjil di Tanah Papua. 